\title{
Agricultural; Provision of Livability or Money?
}

\author{
AR Yavari* \\ Faculty of Environment, University of Tehran-Iran \\ *Corresponding author: AR Yavari, Faculty of Environment, University of Tehran-Iran
}

\section{Introduction}

Following expulsion of Adam \& Eve (attaining knowledge of good and bad or the cause and effect of reproduction) from the "Garden of Eden" their sons Abel \& Cain, were pastoralist and farmer respectively. Abel (pastoralist- nomad as a shepherd) offering to god was accepted but that of cain (grew crops and tilled the land as a farmer) was not. This is despite being a divine knowledge sent from heaven. Products in excess of need are source of income and revenue creating power for subordination and through leisure time to learn and plan is possible for manipulation of future.

\section{Development Issues}

During fifties and sixties plant breeding research program financed by Rockefeller foundation in Mexico was used in Aid Program to combat poverty icreasing susceptability to communism. This transfer of technology in agriculture was called "Green Revolution" and increased yields of wheat when dwarf wheat variety was cultivated in seed bed prepared by deep tillage and large doses of nitrogen used as fertilizers as well as chemicals to protect succulent plants against pathogens and diseases. Land reform was also needed for extensive monoculture to replace scattered fields. Neglecting consequences of land use change valuable indigenous varieties ("Land Races") of wheat were abandoned. A genetic resource loss needed for later crop breeding. It was then that we saw how technology transferred without assessment of its impact may be destructive. Agriculture development neglecting the important role of the context (both natural and cultural) cannot be successfully implemented. Food Bubble is an example of agricultural development based on misleading perspectives resulting to the loss of natural capital and cultural heritage and social disparity. Profound changes appear when heterogeneous rural landscape pattern (repository of indigenous crop varieties, and land races) is altered by land reforms. Ecological resilience and landscape integrity vanish. Modern agriculture is highly dependent on energy and its development linked to trade and globalization with ecological, socio-economic and technical impacts oil and water creating crisis at farm, landscape, regional and national or global scales that remain unattended and without any prospective solution. Use of chemicals and energy have resulted or accelerated climate change. Agriculture is the second most important source of increased nutrient contents soil and water affecting bio-geochemical cycle. Earth atmospheric composition has changed. Tractors alone have increased energy input 100 times with indelible mark on the landscape. Heavy machines and intensive seed bed preparation causes soil compaction and compression altering biological regeneration of soil. Mechanization has encouraged extension of land preparation landscape structure and function increasing soil erosion and use of saline water Machines drived out small producers deteriorating rural life with depression and morbidity through changed landscapes.

\section{Experimental Knowledge}

Active presence of traditional farming demonstrates its effectiveness. Millions of hectares of cultivated land by traditional methods demonstrate successful resilient systems contributing to food security despite increasing presence of climate change. Indigenous knowledge is empirical and experimental acquired by keen observations of what is revealed by nature and accumulated as a valuable collection during centuries. The main repository of this knowledge was found in practices of farming systems. Today part of it is preserved by narrations in folkloric songs and stories. Knowledge contained in traditional agriculture remains a research topic approached by ethnology or anthropology but the wisdom whose example is presented below has scientific and technical values not explored or put to practice:

1. Site selections with proper farm design in respect to configurations of fields or cover types controls wind and water movement used in ventilation or used as vector for propagules.

2. Preserving a balance presence of biodiversity by landscape heterogeneity helps control pests result to enduring disturbances to in order to be able disturbances.

3. Resource constraint may be compensated by use of natural opportunities and specific advantage offered by nature (today called Ecological Services). 
4. For fertilization, pest and weed control companion cropping and rotations is used.

5. Adjusted dates of seeding and harvest is to adapt with harsh conditions; winds and to mitigate pest invasions or to supply crops at best marketing period. Same for transplanting dates of trees for wood during new moon and for fruits during full moon for tall and dwarf tree growth habits respectively.

6. Water as the most important and most limiting resource is only available underground and Qanat(s) or Qarize(s) drain (not pump) water in excess to annual recharge.

\section{Research Topics}

Future sustainable development of agriculture not only depends on above mention issues but it also depends and more so on readjustment of relation we adjustment of relation we have with nature. While hydroponic, salt tolerance, sod seeding, minimum tillage and perma-culture are research topics attracting attention agricultural development needs radical change of perspectives that remains unattended by research. At landscape scale spatial configuration of fields may result to more efficient use of resources in time and space with potential benefits with very little cost of implementation. Improved use of natural and cultural opportunities (similar to those adopted in "Community Conserved Area" strategy for preserving nature) is another rewarding research. Rural land use organization and site selection adopted in semi-arid rural areas called "Deh" (means or is synonym to village) is a living example of how spatial and temporal organization may improve land use efficiency and reduce negative effects of resource constraints through allocation of specific advantages at local level. Each village with similar spatial organization consists of 10 to 50 farms collaborating on communal land. Different ratios of irrigated and dry cultures are decided upon each year according to rain and available water which is extracted by draining (not pumping) underground water to the level of long-term recharge. Two or more "Deh(s)" some located in upland and others in lowland with complementary relations regarding allocation of limited water resources and successful agro-pastoral activities have increased the production capability at regional level. Modern precision technology and improved allocation of ecological services are needed research issues to improve productivity of methods revealed by nature (Table 1 ).

Table 1: Most evident issues and related research topics for major farming systems.

\begin{tabular}{|c|c|c|}
\hline Types & Issue or Deficiency & Proposed R\&D \\
\hline \multirow{4}{*}{ Industrial large-scale monoculture } & Highly resource dependent & \multirow{4}{*}{$\begin{array}{c}\text { Environmental impact assessment \& mitigation } \\
\text { How to include social costs by reducing private } \\
\text { benefits } \\
\text { Improve resilience }\end{array}$} \\
\hline & High social costs & \\
\hline & High environmental costs & \\
\hline & Not resilient & \\
\hline \multirow{3}{*}{ Modern Family Farm } & Resource intensive & \multirow{3}{*}{$\begin{array}{l}\text { Environmental impact assessment \& mitigation } \\
\text { Needs for services }\end{array}$} \\
\hline & Resilient & \\
\hline & Environmental costs & \\
\hline \multirow{3}{*}{ Indigenous or traditional Family Farm } & Resource efficient & \multirow{3}{*}{$\begin{array}{l}\text { Management to replace lost governing body } \\
\text { Optimum modernization and mechanization }\end{array}$} \\
\hline & Highly resilient & \\
\hline & of traditions & \\
\hline \multirow{3}{*}{ Mixed Polyculture /ermaculture } & Improvement in landscape design & \multirow{3}{*}{$\begin{array}{l}\text { Mimic nature in landscape design; field } \\
\text { configuration } \\
\text { Legal support for establishment similar to CCA* }\end{array}$} \\
\hline & Highly resilient & \\
\hline & Need legal and financial support & \\
\hline
\end{tabular}

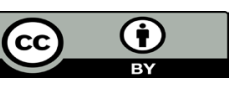

This work is licensed under Creative Commons Attribution 4.0 License To Submit Your Article Click Here: Submit Article

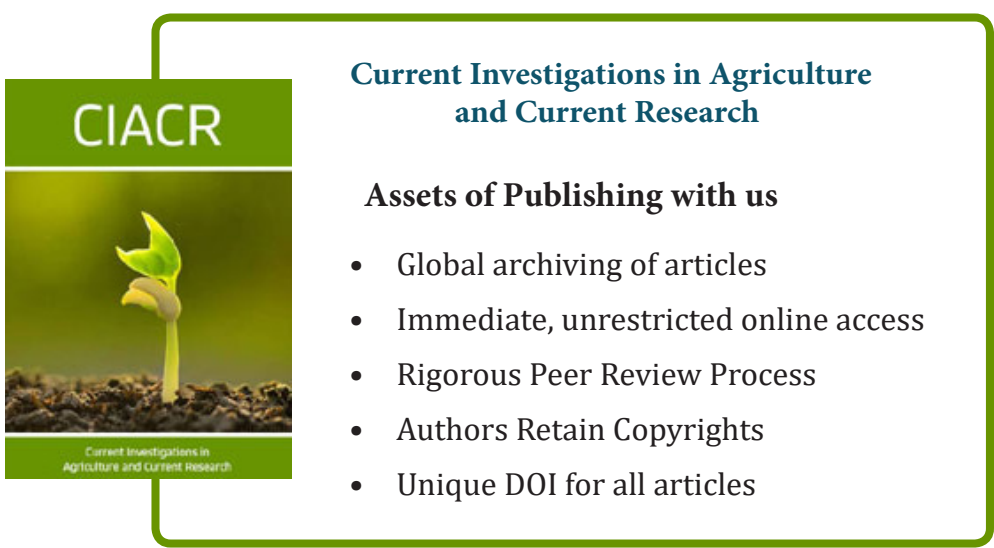

